\title{
e-WIL in Student Education
}

\author{
Michelle W. L. Fong and Robert Sims \\ Victoria University, Melbourne, Australia
}

\author{
Michelle.Fong@vu.edu.au; Robert.Sims@vu.edu.au
}

\begin{abstract}
Higher educational institutions have been compelled by market forces to be more responsive to the needs of their students as well as the demands of different stakeholders - government, industry, professional bodies, and community. The inclusion of WIL (Work-Integrated Learning) curriculum in Australian university programs has become a common strategy to address increasing demands for more practical work related learning in courses. At the same time, as Information Communications Technology (ICT) has become a common teaching and learning resource, its ubiquitous nature means that WIL can also flourish in an online environment. This paper discusses the experience of using asynchronous ICT to implement inclusive e-WIL (electronic Work-Integrated Learning) in the curriculum of an undergraduate business degree subject at Victoria University. It provides insights into the advantages, disadvantages, challenges, and critical success factors of implementing e-WIL activity. The integration of this e-WIL activity has achieved a number of desirable learning outcomes for the students, which will also be discussed.
\end{abstract}

Keywords: Information communications technology; work-integrated learning; online learning environment; collaborative learning; reflective learning.

\section{Introduction}

Since the Dawkins reforms of the late 1980s, the higher education sector in Australia has experienced significant changes to its autonomy and position as a provider of education under a range of Federal government reform policies. Under these changes, universities are moving to a new model of education in which knowledge production and research are no longer carried out solely by, or within, an education institution or segment. These institutions are being compelled by market forces to be responsive to the needs of the students as well as the demands of different stakeholders who, one way or another, exert an influence on the lives and careers of graduates. These demands include governments' desires for universities to be responsive and adaptive to economic needs, students' demand for courses to be more relevant to the workforce, universities' wishes to improve graduate employment outcomes, and businesses' requirements for 'work-ready' graduates who do not require substantial internal training costs to deal with the reality of modern professional practice within a competitive environment (Brodie \& Irving, 2007; Garrick \&

Material published as part of this publication, either on-line or in print, is copyrighted by the Informing Science Institute. Permission to make digital or paper copy of part or all of these works for personal or classroom use is granted without fee provided that the copies are not made or distributed for profit or commercial advantage AND that copies 1) bear this notice in full and 2) give the full citation on the first page. It is permissible to abstract these works so long as credit is given. To copy in all other cases or to republish or to post on a server or to redistribute to lists requires specific permission and payment of a fee. Contact Publisher@InformingScience.org to request redistribution permission.
Kirkpatrick, 1998; McLennan \& Keating, 2008; Reeders, 2000). Driven by market forces, educational institutions have had to review and revamp their products and services to meet these needs. One of the increasingly popular responsive strategies for Australian universities, in their contemporary role as educator and agent of government in responding to economic needs, has been 
the adoption of WIL (Work-Integrated-Learning) as a pedagogy.

WIL has been defined by Precision Consultancy (2007, p. 29) as "the generic term used to describe a range of programs which provide students with a combination of workplace experience and formal learning which are integrated as part of a course of study in higher education." The variations in the nature of experiential learning contexts among various programs make it difficult to derive a more specific definition for WIL. The scoping study of Patrick, et al. (2008, p. 9) identifies several synonymous terms that have been used in referring to WIL, such as "practicum", "professional practice", "internship", "workplace learning", "industry-based learning", "projectbased learning", "work placement", and "cooperative education". The reason for the association of these terms with WIL was that they have been the common approaches adopted by WILoriented universities for students' workplace experience and formal learning in different disciplines or courses (McLennan \& Keating, 2008).

A curriculum that combines on-campus classroom learning with experiential work related learning is gaining increasing interest and acceptance among governments, students, industry, and universities (Abeysekera, 2006; Barnett, Parry, \& Coate, 2001; Coll \& Zegwaard, 2006; Reeders, 2000; Smith, Mackay, Challis, \& Holt, 2006). To provide relevant and meaningful learning experience through WIL, the production of academic capital has frequently moved beyond its traditional boundaries by involving a wider spectrum of stakeholders, including students, government, industry, professional bodies, and community. This change in direction demands inclusive programmes that equalise and promote participation opportunities for students in their interactions with some or all of these stakeholders. Information Communications Technology (ICT), which is increasingly being used to support teaching and learning in the education and training field, can be used to foster strategies for an inclusive WIL pedagogy through technological networking capabilities.

This paper discusses the background to the development of ICT and its increasing interrelationship in e-WIL programs and projects. In that context, a case study analysis is presented of the experience of introducing a community based e-WIL project at Victoria University. Asynchronous ICT was used to implement inclusive e-WIL (electronic Work-Integrated Learning) in the curriculum of an undergraduate business degree subject, Asian Business Environment, at Victoria University. Asynchronous technology was chosen as the medium of communication, collaboration, and cooperation in this subject, after the subject coordinator had considered the learning process of students and the feedback on availability and medium preference from participants in this project. This paper also provides insights into the advantages, disadvantages, challenges, and critical success factors of implementing e-WIL activity through asynchronous ICT. The integration of this e-WIL activity has achieved a number of desirable learning outcomes for the students, which will also be highlighted. In this paper, e-WIL is referred to as online work-based learning, social or collaborative learning, and inquiry-led learning being enabled and empowered by ICT. In e-WIL, learners, instructors, and other stakeholders constitute a learning community being mediated by ICT.

\section{Background: ICT and e-WIL}

ICT has become a common teaching resource in educational institutions. Universities in Australia typically have extensive wireless internet and email facilities as the basic technological platform for a range of online communications and learning support amenities for their students. Advances in ICT have been changing the way education and training are delivered by widening access to, and enabling new approaches to, learning. A common example is 'distance learning' or 'open learning' in which students undertake a course or program online and rarely or never attend oncampus classes. Blended instruction, whereby technology is being used in conjunction with faceto-face teaching to support or complement on-campus classes, is also becoming common in 
higher education. For example, screencasting or podcasting technologies enable lecture sessions to be recorded and later reviewed by students or instructors at any time and place. Because these technologies can liberate education from the constraints of time and distance, they can also be used to promote inclusive practices in WIL. ICT can support either synchronous or asynchronous communication in teaching-learning environment. Synchronous communication (for example through chatrooms) is time-bound and requires the concurrent availability of both the instructor and learners for online interaction. On the other hand, asynchronous communication (for example through threaded discussion board and email) involves participants communicating over elapsed time, thus allowing users to receive or send information at their own pace. Each type of communication has its strengths and weaknesses depending on the context of usage and set of circumstances. As a result, the advantage and disadvantage in each type of communication mode can vary from one teaching-learning environment to another.

\section{An e-WIL and Community Engagement project at VU}

In response to a broad Victoria University (VU) policy to make WIL a universal feature of its degree courses, a community engagement activity was integrated into the curriculum of a business subject, Asian Business Environment, as a vehicle for WIL for onshore students. Students enrolled in this subject attended regular face-to-face classroom sessions in conjunction with online WIL (which is referred to as e-WIL in this paper). The aims of implementing e-WIL in this chosen subject were as follows:

- To provide students with the opportunity to demonstrate their understanding in contexts relevant to the real world.

- To provide opportunities through online learning environments for students to interact with individuals from diverse cultures and encounter various perspectives and points of view, whereby they can evaluate their own values and views.

- To encourage learners to construct new knowledge individually and in interaction with others and to develop this new knowledge based on prior knowledge or experience.

- To create a learning environment in which students acquire competence through their interaction with peers, university staff members, industry personnel, overseas parties, and community members.

- To help students acquire skills for lifelong learning - A key characteristic of lifelong learning is strongly connected with critical and reflective thinking (Brookfield, 1995).

The community engagement activity involved the recycling of surplus or unwanted textbooks, donated by academics in the Faculty of Business and Law, by forwarding these books to the libraries of four educational institutions in China. These educational institutions were selected as worthy recipients because they lack sufficient English textbooks in their libraries to adequately cater for the learning needs of students in their business educational programs. These institutions wanted to improve access to English references for their students and academics, to assist their learning, teaching, and research, but they found it difficult and expensive to procure these references from abroad. TNT Australia Pty Limited, a company well-known for its logistics, mail, and express delivery services in Australia and worldwide, generously offered its services as industry partner and transportation sponsor for delivering the textbooks to the chosen Chinese institutions.

Four teams, each consisting of about seven onshore students, were involved in this engagement activity. Each team was assigned responsibility for recycling textbooks to a particular Chinese institution as an e-WIL project. All teams were given considerable discretion to plan and execute their activities in order to optimally achieve their objective. This WIL project required the student 
teams to work with each other, staff in the university, and relevant personnel in overseas and local organisations. Because response time and task duration can vary greatly, depending on the class or personal schedule of students and stakeholders available for interaction, it was not possible for students to execute their projects strictly within classroom hours. As a result, the subject coordinator designed WIL activities that could be facilitated by asynchronous ICT commonly in use within the university, workplace, and home, to provide flexibility to students in managing their projects. Generally, students used asynchronous communications and web-based technology such as BlackBoard, a course management tool, and email systems, to complete their tasks. Figure 1 shows the required communication links between students in a project team and the different stakeholders.

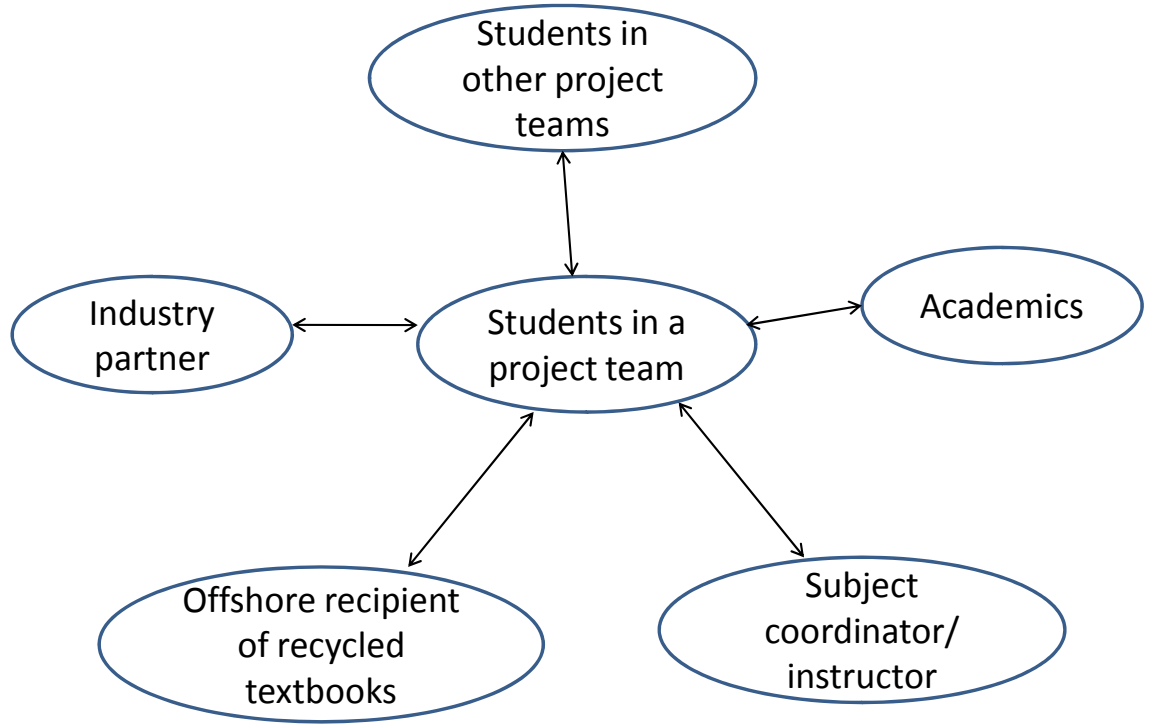

Figure 1 - Communication links between students in a given project team and the different stakeholders.

In essence, this project was designed to provide an authentic professional context as a learning environment in which students engage in meaningful and consequential workplace activities. In this authentic setting, students were exposed to real world problems and issues that required practical solutions. The WIL process provided opportunities for students to integrate workplace experience and disciplinary knowledge and practice or to apply the theory of their discipline to real world context. One of the principles underlying WIL is that students are more inclined to acquire skills and competence through concrete experience rather than abstract, hypothetical problems posed by teachers in a traditional classroom teaching. This project aimed to develop students professionally as job-ready graduates and personally as responsible citizens with a sense of civic conscience.

The e-WIL curriculum is designed based on constructivist principles which engage students in ways that require reflection and demonstrated knowledge construction. Through the e-WIL project, students construct knowledge individually and through interaction with others (that is, learning by creating meaning from different experiences) with the instructor as a guide, mentor, and facilitator to assist them. In constructivist learning, students self-regulate their learning process and control their own learning activities. All teams in the book-recycling project were given con- 
siderable discretion to plan and execute their activities in order to achieve their objectives. They were expected to manage the information to be learned, monitor their thinking processes, and seek help when required. The instructor mostly played the role of an informal team member to facilitate in building healthy, collaborative, and functioning teams. The intention was to establish an atmosphere that makes learners feel comfortable and supported when considering new ideas for accomplishing e-WIL outcomes (Laird, 1985). Mostly this involved working informally with the teams and monitoring and contributing to some of the online discussions. Occasionally the instructor needed to exercise appropriate intervention to ensure respectful discussions were being conducted by students on the online threaded discussion board. A threaded discussion board can be a powerful tool in developing skills in a collaborative and cooperative setting if it is integrated into the curriculum with careful planning and moderated appropriately (Harman \& Koohang, 2005; Koohang, Riley, Smith, \& Schreurs, 2009). Students were also mentored by their instructor when they interacted with people from external professional organisations, such as industry personnel and overseas counterparts. Mentoring was aimed at ensuring that students interacted professionally and sensitively so that existing relationships with these external parties were not jeopardised and so that the learning experience became meaningful and relevant for the students. To achieve this, students were required to keep their instructor informed of all correspondence with stakeholders by way of ensuring that the instructor was always included in the "cc" field of their emails to stakeholders. This allowed the instructor to monitor student communications with the different stakeholders and guide the students when necessary. This is in contrast to traditional classroom teaching, where the instructor typically exercises considerably more direct control over the students' learning activities.

Various studies (Australian Universities Teaching Committee, 2009; Chickering \& Gamson, 1991; Collier, 1980; Goodsell, Maher, \& Tinto, 1988; Ma, 2009; Rosen \& Rimor, 2009; Slavin, 1980,1983 ) have revealed that learning outcomes improve when learners are working collaboratively in groups. This is a central premise of Vygotsky's (1978) theory of social development, which suggests that social interaction plays a fundamental role in the development of cognition. On this basis, computer-mediated communication technology was adopted in this project to create a social learning environment and to leverage the strength of social interaction for e-WIL. The Group-Investigation method (Sharan \& Sharan, 1989, 1994) was also adopted in the e-WIL process as a proven method to better engage students in learning. This method calls for students to set their own goals, explore appropriate resources, allocate subtasks among group members, and work with others in groups and across groups to pursue inquiry tasks of their own. In this way, students not only learn to learn by themselves, but also learn through others. Such group activities help to foster the development of independent thinking and reflection based on one's background and the realisation of others (Crosling \& Marin, 2005). This not only instils students with a sense of ownership of their own learning, but also equips them with skills for managing their own learning for life, because successful participation can lead to internalization (Roschelle, 1995).

Reflective practice is another important aspect of effective learning. In this project, online journals were used to generate students' critical reflections of the e-WIL experience. A number of studies have shown that critical reflection can be a powerful tool for improving the learning process of students because it encourages individuals to make meaning of situations through inquiry into their learning and underlying assumptions, as well as the consequences of their actions (Bullough \& Gitlin, 2001; Dinkelman, 2003; Loughran, 2002; Zeichner \& Liston, 1987). In other words, reflection provides opportunities for the students to integrate work experience and disciplinary knowledge and practice. This can engender deep and meaningful learning because it allows experience to be actively considered and analysed against theoretical knowledge (Biggs, 1999; Brookfield, 1995). In this project, students were required to write and describe in their online journal their critical thoughts about their e-WIL experiences from the textbook recycling project, including the types of problems they had worked through, the lessons they had learned 
and their suggestions for improvement. These online journals helped strengthen the reflective learning, because they allowed the instructor to interact with the students and to provide feedback to assist individual students to achieve specific learning outcomes and enhance their learning experience. In this way, technology helped to ensure a learner-centred approach to learning.

\section{e-WIL Activities}

The following e-WIL activities were undertaken by the students:

\section{1) Brainstorming}

All team members were required to discuss/brainstorm with each other within their teams through the BlackBoard discussion board before each formal tutorial session. This is because tutorial sessions are very short, and preliminary discussions would ensure that each tutorial was used for advanced comments, ideas, and discussion. The meeting time and place for such preliminary discussions were at the discretion of each team. After these discussions, all teams met in a formal tutorial session, where each team presented and reviewed its preferred handling process with other teams and critiqued each other's processes. This provided a good opportunity for participating students to review everyone's understanding of the textbook recycling project as well as developing best practice guidelines for the project's development. Each team also consulted the stakeholders for their input on the preferred logistics process. These stakeholders included the academics who donated the textbooks, the industry partner sponsoring the transportation (TNT), and the Chinese institutions receiving the textbooks.

\section{2) Collection and distribution of surplus or unwanted textbooks}

To prevent duplication of effort, the students decided that each team should approach academics from a particular school in the Faculty of Business and Law for donation of their surplus or unwanted textbooks. This was largely done through emails or telephone calls, although some students approached the academics personally. Each team liaised with the academics that responded to their requests and negotiated a collection time and day and delivery mode, to determine whether the academic preferred to send books through internal mailing, external post, or collection in person). After the collection of all donated books, the teams met with each other to classify all the textbooks collected and discuss the distribution destination for each textbook. Prior to this discussion, teams carried out background Internet research on the types of business course offered by each institution, so that they could make informed decisions on the most suitable textbooks for each institution.

\section{3) Liaising with the Chinese educational institutions}

Each team liaised with its allocated overseas educational institutions via email to confirm the suitability of the list of books, any procedure involved to clear customs and excise requirements, and the delivery arrangements.

\section{4) Processing and packing of textbooks}

Once the overseas recipients confirmed the list of textbooks for their libraries, the teams convened to process, sort, and pack the books for delivery by TNT, the transportation sponsor.

5) Liaising with industry partner, TNT Australia Pty Limited

Each team consulted with relevant TNT staff regarding delivery details. The students acted as agents between TNT and the overseas recipients to communicate the delivery arrangements. 


\section{Evaluation and Case Analysis}

\section{Methodology}

At the end of the project a series of evaluations were conducted. Staff involved in the project were interviewed to obtain their perceptions about the project and the outcomes. Interviews comprised open ended questions and responses were tape recorded and subsequently analysed. All students completed an evaluation survey, containing a mix of closed and open ended questions. Responses were noted and qualitative comments were analysed to identify key themes. The researchers followed Miles and Huberman's (2002) approach of interrogating data for themes and of using matrices to record common themes and perceptions about strengths and advantages of eWIL as well as perceived problems and challenges and how to deal with them.

\section{Advantages and Disadvantages/Challenges of e-WIL}

The analysis of student and staff evaluations revealed a number of perceived advantages as well as some disadvantages and challenges of implementing e-WiL through asynchronous communications technology. These are listed in Table 1.

Table 1 - Advantages and disadvantages/challenges of e-WIL

\begin{tabular}{|c|c|}
\hline Advantages & $\begin{array}{l}\text { - } \quad \text { Learner-centred. } \\
\text { - } \quad \text { Flexibility (self-paced and experiential learning is not workplace bound). } \\
\text { - } \quad \text { No time constraint in asynchronous communication. } \\
\text { - } \quad \text { No location constraint. } \\
\text { - } \quad \text { Involves global or external participants. } \\
\text { - } \quad \text { Facilitates collaboration and communication. } \\
\text { - } \quad \text { Online communications and submissions constitute archival evidence } \\
\text { that can be used for review and tracking of learning process. }\end{array}$ \\
\hline $\begin{array}{l}\text { Disadvantages/ } \\
\text { Challenges }\end{array}$ & $\begin{array}{l}\text { - } \quad \text { Lack of immediate feedback in asynchronous communication. } \\
\text { - } \quad \text { Lack of audio and video cues in asynchronous communication. } \\
\text { - } \quad \text { Time-consuming in the development and monitoring of e-WIL. } \\
\text { - } \quad \text { In e-WIL, subject coordinator can face significant pressure in sourcing a } \\
\text { range of meaningful real world learning opportunities, which are relevant } \\
\text { and can be leveraged by ICT, for the curriculum. } \\
\text { - } \quad \text { Undeveloped or weak IT infrastructure can hamper and frustrate e-WIL. } \\
\text { - } \quad \text { Students who are not familiar with the use of technology may feel frus- } \\
\text { trated and confused by e-WIL. } \\
\text { - Making e-WIL accessible and inclusive for large numbers of students can } \\
\text { be a challenge. }\end{array}$ \\
\hline
\end{tabular}

\section{Advantages}

One of the advantages of using asynchronous communications technology in this e-WIL project is that conversation can occur at times and places which are convenient for all concerned. Messages can be retrieved and responded to whenever convenient for the receiver and for however long the participants desired. In addition, this technology enabled a student-centred learning approach where students were able to take control of their acquisition of knowledge and skills and were able to juggle existing paid employment, family, and study commitments whilst engaging in e-WIL. This catered better not only to the lifestyle of each student but also to his/her respective 
learning pace. As each student does not learn in the same way, asynchronous technology provided time for him or her to synthesize and analyse information before formulating a question or comment. Several good ideas were generated through online collaborative learning and discussions. For example, a number of best work practices were developed for the e-WIL projects - one of which was the establishment of an organised structure for each of the teams, with various team members adopting designated roles such as team leader/project manager, liaison officer, information officer, logistics officer, campaign officer, and report coordinator. In addition, one team suggested that goodwill with the overseas institutions could be improved by labelling each book with a complementary slip containing the logos and contact details of Victoria University and TNT Australia Pty Limited. This suggestion was happily adopted by the subject coordinator and industry partner.

The asynchronous ICT not only allowed learning dialogues to be sustained independent of class time and distance, but also allowed the instructor to confirm that learning was happening outside classes and to provide guidance when necessary. Through e-WIL, experiential learning was not necessarily bound to the workplace, which removed any pressure on the instructor to visit the workplaces to assess students; instead the instructor was able to observe and monitor the students' work integrated learning through their email correspondences with the stakeholders and threaded discussions with their peers. These emails and online discussion threads served as archival information which allowed the instructor to track and assess students' progress in knowledge construction and to assist in their learning progress. This retrievable digital information also allowed students and the instructor to review and reflect on what had been discussed and learned.

In e-WIL, the networking capability of ICT offered flexibility and useful opportunities for students to interact with their instructor, industry personnel, and overseas parties. For example, students were able to liaise with the instructor via email without having to wait for class time or office hours. In addition, students were also able to approach industry personnel for expert advice without having to compete for appointment times in their busy corporate schedules. Furthermore, students were able to interact with overseas parties and to directly engage with people from diverse ethnic and linguistic backgrounds in a practical environment. In this way, learning was not only contextualized within a working environment but also within a varied socio-cultural context of various participants.

Through emails and online threaded discussion, learners had the opportunity to actively construct knowledge by formulating ideas into words that are shared with and built upon through the reactions and responses of others. The written communications improved the writing skill of the students, who were required to articulate clear and explicit ideas, questions, and arguments in their writings. This form of communication also forced students to think their ideas through thoroughly, which in turn sharpened their critical thinking abilities. The asynchronous nature of these discussions allowed equitable participation from users. In addition, the relative anonymity and security afforded by these computer-mediated communications technologies helped to overcome some users' potential anxiety they may have encountered in face-to-face communication with external parties.

\section{Disadvantages/Challenges}

The asynchronous communications technology used in e-WIL does not demand that users provide spontaneous responses to comments and questions because the sender and receiver are not concurrently engaged in communication. As a result, instructors, students and stakeholders can work at their own convenience on this asynchronous communication platform and students may not obtain timely feedback, which can have a significant impact on student learning quality (Black \& William, 1998; Irons, 2008). Another challenge posed by asynchronous communications technology is that the threaded discussion board and email used by students for communications and 
knowledge construction lack the face-to-face interaction of a classroom (Rice \& Love, 1987). Instructors must be positive and encouraging in their written communication with students because motivation is important in order to get them interested and engaged in learning (Brewster \& Fager, 2000). Higher motivation and engagement in learning have been found to be related to reduced student attrition rates and increased levels of student success (Blank, 1997; Dev, 1997; Kushman, Sieber, \& Heariold-Kinney, 2000; Stone, 2005; Tinto, 1993; Woods, 1995). As a result, instructors must not only provide timely and clearly expressed feedback to the students but also ensure that their comments are positive and constructive to motivate students in their learning process (Holmes \& Smith, 2003). In this business subject, which involved blended instruction, the instructor was able to reinforce earlier written feedback through face-to-face interaction during formal tutorial sessions.

Designing and monitoring e-WIL curricula and activities can be very time-consuming and difficult. The subject coordinator can face substantial pressure in integrating appropriate work or engagement activities which are suitable for e-WIL and provide relevant, meaningful, and worthwhile experiential work integrated learning opportunities for students. In addition, instructors are likely to find themselves spending more attention, time and energy in e-WIL than traditional classroom delivery demands. For example, communication for academics who adopt an e-WIL curriculum will tend to be multi-directional with different stakeholders, rather than simply twoway dialogue between themselves and the students. In addition, the large numbers of students involved can make it challenging for the instructor to provide proper attention to all.

Victoria University's networking capability supported e-WIL at the global level in this project, and students were able to interact effectively with overseas parties. However, an unreliable or weak ICT infrastructure in overseas developing countries could frustrate attempts to expand eWIL to the global level or to maintain a sustainable online WIL global environment. In addition, students who are not familiar with the use of technology or have limited ICT knowledge may feel frustrated and confused by e-WIL. All these can create stresses which can affect the learning environment.

Because the e-WIL curriculum is intrinsically based on constructivist principles in which the students take control of their learning process, there is also a risk that some students who lack sufficient self-discipline may fall into procrastination. This may lead to frustration and stress due to information overload when they attempt to rush their learning progress at the last minute before the semester ends. It may also jeopardise relationships with industry partners and stakeholders if they feel they have been let down or poorly treated by the students.

\section{Critical Success Factors}

Based on the experience of integrating e-WIL component into the Asian Business Environment subject curriculum at Victoria University, the critical factors for ensuring the success of e-WIL have been identified as follows.

In order to ensure worthwhile e-WIL experiences, there must be clear agreement and shared understanding of purpose among the different stakeholders as to how each of their roles impacts upon the student learning experience. The subject coordinator needs to be responsible for providing detailed briefing to all parties. For example, the purpose and benefits of e-WIL had to be explicitly conveyed to the industry partner and the offshore recipients of the recycled textbooks. Mutual agreement must also be solicited from these parties in the event of unexpected changes in the e-WIL project. Therefore, it is important that the subject coordinator and instructor keep in close communication with these external parties in order to maintain a cooperative relationship and to provide relevant, meaningful and worthwhile learning experiences for students. 
Students must also be well informed of their role and responsibilities in the e-WIL project. They must be willing to engage in open exchange and communication online in order for productive learning to occur. They must not only take responsibility for accomplishing the tasks involved in the project and must seek clarification when necessary, they also need to be proactive in reading posted announcements and getting course materials off BlackBoard.

To better support e-WIL through teamwork, guidelines must be posted and agreed upon for successful teamwork conduct and for professional communication protocols, both within teams and with external stakeholders. In this project, everyone was required under the guidelines to participate in inclusive and respectful discussion. For example, team members were expected to show respect for others by giving everyone a chance to voice his or her opinion and ensuring that no one devalues others' cultural ways of learning or practising. They were also expected to demonstrate respect and sensitivity in correspondence with busy external stakeholders.

While e-WIL at the global level can bring diversity to student learning, an adequate and reliable ICT infrastructure (whether locally or overseas) is a crucial requirement. Whether e-WIL delivers its undoubted potential depends to a large extent on the availability and reliability of ICT communications and also on the extent to which ICT is strategically exploited and planned. If students are not able to access ICT resources because of financial constraints, insufficient open access work stations at university, or unreliable server systems for outside access, they will not have the necessary opportunity to use ICT for e-WIL at suitable times according to their needs. Sufficient access to ICT resources, reliable support services and high quality equipment are indispensable conditions to achieve the necessary support of ICT for e-WIL. Ideally, there should be a back-up strategy to meet any contingencies and to maintain a sustainable on-line WIL environment in case of unexpected downtime in ICT infrastructure or technical faults.

Developing the skills to engage effectively with the technology for e-WIL is another important requirement for the students, subject coordinator, and instructor. The impact of ICT application for e-WIL depends on the capacity of the subject coordinator to exploit it efficiently for pedagogical purposes. At the same time, students must be equipped with the technology knowledge and skill to handle e-WIL, and the instructor must be in a position to prepare students for e-WIL and assist them with any problems. Common barriers to using technology by teachers include lack of time, limited skill, fear of technology, and limited access to technology (Kay, Knaack, \& Petrarca, 2009), which must be eliminated before ICT can be effectively harnessed for e-WIL. Therefore, effective preparation and training is crucial for all concerned so that everyone is confident in handling ICT and using ICT in an effective way for work-integrated learning. This also raises a critical issue that universities must be prepared to support and invest resources for e-WIL, in particular to finance reliable ICT infrastructure, offer staff training, and provide a supportive workload model that affords academic staff the additional time needed to design, develop, and manage e-WIL curricula. Without senior management support for e-WIL in the curriculum, the scope of achievement and depth of engagement may be greatly affected.

In e-WIL, the subject coordinator and instructor play several roles - pedagogical, facilitating, regulatory, guidance/mentoring, and networking - that are critical to the successful implementation of e-WIL, as shown in Table 2. This represents a departure from the more limited roles demanded by a traditional teaching approach. In designing and developing e-WIL curricula, the subject coordinator must give important consideration, in his/her pedagogical role, to the subject content, technology applications, and facilitation of e-WIL. In addition, the e-WIL curriculum must provide a range of relevant, meaningful, and worthwhile learning opportunities for the students. In considering technology applications for e-WIL, commonly used and reliable ICT must be adopted for communications and knowledge construction. Email, the easiest to use of all forms of ICTs, and widely regarded as the least threatening and easiest to manage, was the common 
communication mode in this e-WIL project. With the emergence of so many online networking applications this may not always be the case.

Whatever the communication tool used in the facilitation of e-WIL, the process must be properly structured, supervised, and assessed. There also needs to be effective tracking of the students' progress in terms of preparation for the e-WIL project, participation in the project, monitoring and assessment of the learning, and final evaluation of the impact of learning. While the subject coordinator also sets the guidelines for appropriate learning behaviour, the instructor largely plays facilitating, regulatory, and guidance/mentoring roles to ensure behaviour compliance from students and, also, in helping students to establish the link between their experiences and curriculum content. For example, the subject coordinator (in his/her pedagogical role) develops formative assessment procedures and sets up online journal entries for the instructor and the students to monitor guidance and /mentoring roles as well as student learning progress.

The coordinator and instructor need to also actively promote student's self-efficacy in online settings to reduce procrastination, and, in their guidance/mentoring role, instructors must be able to exercise an appropriate level of guidance for students. It can be a challenge for the instructor to provide the correct amount of guidance; too much direction may inhibit the development of a sense of ownership in learning (Candy, 1991). On the other hand, insufficient direction may result in a loss of purpose and urgency. Furthermore, although instructors can work at their own convenience because of computer-mediated-communications' asynchronicity, timely and useful feedback is pivotal to student learning. Otherwise, e-WIL may merely prompt students to conclude that this form of learning is more time-consuming and involves more effort than face-toface learning in a classroom. For example, when students are confronted with a problem while engaging in e-WIL and their request for guidance or assistance from their instructor is delayed because of asynchronous communication technology, there is a risk students may become discouraged or lose motivation. If timely feedback is of essence in a subject curriculum, synchronous technology will have to be considered for use in e-WIL environment. However, the advantage of timely feedback gained from this technology will have to be weighed against the loss of advantages associated with asynchronous communication. Finally, the networking role has to be played by both the subject coordinator and instructor, who are jointly responsible for maintaining interest and support from the other stakeholders in order to ensure their continued participation.

Table 2 - Roles of subject coordinator and instructor

\begin{tabular}{|l|l|}
\hline Roles & Examples of activities \\
\hline Pedagogical role & $\begin{array}{l}\text { Design e-WIL curricula that provide a range of meaningful, real- } \\
\text { world learning opportunities that can be leveraged by ICT. }\end{array}$ \\
\hline Facilitating role & $\begin{array}{l}\text { Encourage student critical thinking and inquiry by asking thoughtful, } \\
\text { open-ended questions, and prompting students to pose questions to } \\
\text { each other. Scaffold online discussions in an effort to enhance stu- } \\
\text { dents' use of critical thinking skills. Prompt passive students to par- } \\
\text { ticipate. }\end{array}$ \\
\hline Regulatory role & $\begin{array}{l}\text { Remain as an informal member of each team to facilitate in building } \\
\text { healthy, collaborative and functioning teams. Instructor must be pre- } \\
\text { pared to moderate if needed to prevent discussion from degenerating } \\
\text { into unhealthy behaviours such as exchange of insults or derogatory } \\
\text { remarks. Exercise appropriate intervention aimed at promoting stu- } \\
\text { dent's self-efficacy in online settings to reduce procrastination. }\end{array}$ \\
\hline
\end{tabular}




\begin{tabular}{|l|l|}
\hline Roles & Examples of activities \\
\hline Guidance/mentoring role & $\begin{array}{l}\text { Respond to questions, and issue advice and guidance. Boost the con- } \\
\text { fidence of weaker students in the e-WIL process. }\end{array}$ \\
\hline Networking role & Maintain the interest and support of the other stakeholders. \\
\hline
\end{tabular}

\section{Learning Outcomes of e-WIL}

Analysis of the evaluation surveys conducted at the end of the teaching semester strongly indicated that the aims of implementing e-WIL through asynchronous ICT were achieved in this subject. There were no negative comments about the overall learning experience from the e-WIL project. Students commonly acknowledged a number of positive learning benefits. In particular they reported that they had learned:

- to reflect on their understanding and development;

- to appreciate the value of the formative activity as a learning opportunity;

- to understand more what it means to be a professional, particularly through their dealings with external parties in a work setting;

- to be more aware of diversity within their own team and in local and international communities and, more importantly, how to deal more effectively with diversity;

- to be more tolerant towards others' values and cultures;

- to recognise and value different opinions in solving problems;

- to see each other as resources, learn from each other, and appreciate others' points of view;

- that they discovered things they had never realised about themselves;

- that they were empowered as self-regulated learners (taking responsibility for their own learning, and becoming active and engaged learners);

- a range of generic skills for graduate employability; and

- many of the subject's expected learning outcomes had been achieved via the project.

\section{Conclusions}

This case study described the use of asynchronous ICT to integrate a community project in a subject curriculum for meaningful e-WIL for students. This technology was used to create constructivist learning opportunities and support reflective practices in an authentic global environment, with the aims of developing student employability capabilities and civic responsiveness. The analysis of the e-WIL project and the feedback from student evaluation surveys confirmed the success of the project and the achievement of these aims. Advantages associated with the use of asynchronous technology for e-WIL were identified. For example, this technology allows flexibility in communication because it is not time or location bound. In addition, it affords time to students to reflect on their interaction and participation before composing their own response and this offers students the opportunity to develop higher-order thinking. Electronic network connectivity exposes students to greater diversity in perspectives through their interaction with peers, community members, and global participants. The archival feature of communication media such as email and threaded discussion boards provides rich support for review and reflection for students and academics. However, there are drawbacks and challenges that curriculum designers 
have to be aware of when using asynchronous technology, such as the lack of immediate feedback and interactivity which may generate a sense of alienation for some students. In addition, academics can face substantial pressure in effectively deploying and using ICT in an effort to engage and motivate students in e-WIL.

Lastly, this case study identified a number of critical factors for ensuring the success of e-WIL. A clear plan and structure of operations is important for achieving the aims of e-WIL. In addition, universities must be prepared to support and invest for stable ICT infrastructure and capabilities in order to enable e-WIL to be efficient and meaningful. Academics must also be prepared to play several roles (pedagogical, facilitating, regulatory, guidance/mentoring, and networking) in eWIL as compared to limited roles in traditional teaching approach.

\section{Future Research: Synchronous Communication in e-WIL}

This project used asynchronous technology for e-WIL. Some of the advantages and disadvantages associated with the use asynchronous communication identified in earlier sections may be enhanced, aggravated, or diminished if synchronous communication was adopted instead or in conjunction with asynchronous communication. For example, synchronous sessions may make participants feel less isolated because real-time interactivity can assist in creating a collegiate atmosphere for collaborative learning (Skylar, 2009; Stephens \& Mottet, 2008). However, the use of synchronous technology can reduce flexibility in communication and time for critical thinking in the participation process for students, as compared to asynchronous technology (Armitt, Slack, Green, \& Beer, 2002; de Bruyn, 2004). The use of synchronous communication in e-WIL warrants further investigation and research, including the possibility of hybrid use of both asynchronous and synchronous communications to harness the best technological offers for enhancing eWIL.

\section{References}

Abeysekera, I. (2006). Issues relating to designing a work-integrated learning program in an undergraduate accounting degree program and its implications for the curriculum. Asia-Pacific Journal of Cooperative Education, 7, 7-15.

Armitt, G., Slack, F., Green, S., \& Beer, M. (2002). The development of deep learning during a synchronous collaborative on-line course. Proceedings of Computer Support for Collaborative Learning, Boulder, Colorado, USA, 151-159. Retrieved on 12 March 2010 from http://www.cis.drexel.edu/faculty/gerry/cscl/cscl2002proceedings.pdf

Australian Universities Teaching Committee. (2009). Assessing learning in Australian Universities: Ideas, strategies and resources for quality in student assessment. Retrieved on 8, October 2009 from http://www.cshe.unimelb.edu.au/assessinglearning

Barnett, R., Parry, G., \& Coate, K. (2001). Conceptualising curriculum change. Teaching in Higher Education, 6, 435 - 449.

Biggs, J. (1999). Teaching for quality learning at university: What the student does. Buckingham: Open University Press.

Black, P., \& William, D. (1998). Assessment and classroom learning. Assessment in Education, Principles, Policy and Practice, 5(1), 7-73.

Blank, W. (1997). Authentic instruction. In W.E. Blank \& S. Harwell (Eds.), Promising practices for connecting high school to the real world (pp.15-21). Tampa, Florida: University of South Florida.

Brewster, C., \& Fager, J. (2000). Increasing student engagement and motivation: From time-on-task to homework. Retrieved October 13, 2009 from http://www.nwrel.org/request/oct00/textonly.html 
Brodie, P., \& Irving, K. (2007). Assessment in work based learning: Investigating a pedagogical approach to enhance student learning. Assessment and Evaluation in Higher Education, 32(1), 11-19.

Brookfield, S. (1995). Becoming a critically reflective teacher. San Francisco: Jossey-Bass.

Bullough, R. V., Jr., \& Gitlin, A. (2001). Becoming a student of teaching: Methodologies for exploring self and school context (2nd ed.). London: Routledge Falmer.

Candy, P. C. 1991. Self-direction for lifelong learning. San Francisco, California: Jossey-Bass Higher and Adult Education Series.

Chickering, A. W, \& Gamson, Z. F., Eds. (1991). Applying the seven principles for good practice in undergraduate education. New directions for teaching and learning, no.47. San Francisco: JosseyBass.

Coll, R. K., \& Zegwaard, K. E. (2006). Perceptions of desirable graduate competencies for science and technology new graduates. Research in Science and Technological Education, May, 24(1), 29-58.

Collier, K. G. (1980) Peer-group learning in higher education: The development of higher-order skills. Studies in Higher Education, 5(1), 55-62.

Crosling, G., \& Martin, K. (2005). Student diversity and collaborative learning: A positive combination for curriculum internationalisation. In E. Manalo \& G. Wong-Toi (Eds.), Communication skills in university education: The international dimension (pp. 136-149). Auckland: Pearson Education New Zealand.

de Bruyn, L. L. (2004). Monitoring online communication: Can the development of convergence and social presence indicate an interactive learning environment? Distance Education, 25(1), 67-81.

Dev, P. C. (1997). Intrinsic motivation and academic achievement: What does their relationship imply for the classroom teacher? Remedial and Special Education, 18(1), 12-19.

Dinkelman, T. (2003). Self-study in teacher education: A means and ends tool for promoting reflective teaching. Journal of Teacher Education, 54(6), 6-18.

Garrick, J., \& Kirkpatrick, D. (1998). Workplace-based learning degrees: A new business venture, or a new critical business? Higher Education Research and Development, 17(2), 171-182.

Goodsell, A. S., Maher, M. R., \& Tinto, V., Eds. (1992). Collaborative learning: A sourcebook for higher education. National Center on Postsecondary Teaching, Learning, \& Assessment, Syracuse University.

Harman, K., \& Koohang, A. (2005). Discussion board: A learning object. Interdisciplinary Journal of ELearning and Learning Objects, 1, 67-77. Retrieved from http://www.ijello.org/Volume1/v1p067077Harman.pdf

Holmes, L., \& Smith, L. (2003). Student evaluation of faculty grading methods. Journal of Education for Business, July/August, 318-323.

Irons, A. (2008). Enhancing learning through formative assessment and feedback. New York: Routledge.

Kay, R. Knaack, L., \& Petrarca, D. (2009). Exploring teachers' perceptions of web-based learning tools. Interdisciplinary Journal of E-Learning and Learning Objects, 5, 27-50. Retrieved from http://www.ijello.org/Volume5/IJELLOv5p027-050Kay649.pdf

Koohang, A., Riley, L., Smith, T., \& Schreurs, J. (2009). E-learning and constructivism from theory to application. Interdisciplinary Journal of E-Learning and Learning Objects, 5, 91-109. Retrieved from http://www.ijello.org/Volume5/IJELLOv5p091-109Koohang655.pdf

Kushman, J.W., Sieber, C., \& Heariold-Kinney, P. (2000). This isn't the place for me: School dropout. In D. Capuzzi \& D. R. Gross (Eds.), Youth at risk: A prevention resource for counselors, teachers, and parents (3rd ed.) (pp.471-507). Alexandria, VA: American Counseling Association.

Laird, D. (1985). Approaches to training and development. Reading, Mass: Addison-Wesley.

Loughran, J. J. (2002). Effective reflective practice: In search of meaning in learning about teaching. Journal of Teacher Education, 53(1), 33-43. 
Ma, A. W. W. (2009). Computer supported collaborative learning and higher order thinking skills: A case study of textile studies. Interdisciplinary Journal of E-Learning and Learning Objects, 5, 145-167. Retrieved from http://www.ijello.org/Volume5/IJELLOv5p145-167MA657.pdf

McLennan, B., \& Keating, S. (2008, June). Work-integrated learning (WIL) in Australian Universities: The challenges of mainstreaming WIL. ALTC NAGCAS National Symposium, Melbourne, June 2008. Retrieved 7, January 2009 from http://tls.vu.edu.au/vucollege/LiWC/resources/NAGCASpaperfinal10June08.pdf

Miles, M., \& Huberman, M. (2002). Qualitative Data Analysis: An Expanded Sourcebook (2nd ed.). London: Sage Publications.

Patrick, C-J., Peach, D., Pocknee, C., Webb, F., Fletcher, M., \& Pretto, G. (2008, December). The WIL [Work Integrated Learning] report: A national scoping study [Australian Learning and Teaching Council (ALTC) Final report]. Brisbane: Queensland University of Technology. Retrieved 13, October 2009 from http://www.altc.edu.au and http://www.acen.edu.au

Precision Consultancy. (2007, August). Graduate employability skills: Prepared for the business, industry and higher education collaboration council. Retrieved 8, January 2009, from http://www.dest.gov.au/highered/bihecc

Reeders, E. (2000). Scholarly practice in work-based learning: Fitting the glass slipper. Higher Education Research and Development, $19(2), 205-220$.

Rice, R. E., \& Love, G. (1987). Electronic emotion: Socioemotional content in a computer-mediated communication network. Communication Research, 14, 85-108.

Roschelle, J. (1995). Learning in interactive environment: Prior knowledge and new experience. In J. H. Falk \& L. D. Dierking, (Eds.), Public institutions for personal learning: Establishing a research agenda (pp. 37-51). Washington, D. C.: American Association of Museums.

Rosen, Y., \& Rimor, R. (2009). Using a collaborative database to enhance students' knowledge construction. Interdisciplinary Journal of E-Learning and Learning Objects, 5, 187-195. Retrieved from http://www.ijello.org/Volume5/IJELLOv5p187-195Rosen671.pdf

Sharan, Y., \& Sharan, S. (1989). Group investigation expands cooperative learning. Educational Leadership, 47(4), 17-21.

Sharan, Y. \& Sharan, S. (1994). Group Investigation in the cooperative classroom. In S. Sharan (Ed.), Handbook of cooperative learning methods (pp. 97-114). Westport, CT: Greenwood Press.

Skylar, A. A. (2009). A comparison of asynchronous online text-based lectures and synchronous interactive web conferencing lectures. Issues in Teacher Education, 18(2), 69-84.

Slavin, R. E. (1980). Cooperative learning. Review of Educational Research, 50(2), 315-342.

Slavin, R. E. (1983). When does cooperative learning increase student achievement? Psychological Bulletin, 94(3), 429-445.

Smith, R., Mackay, D., Challis, D., \& Holt, D. (2006). Seeking industry perspectives to enhance experiential education in university-industry partnerships: Going beyond more assumptions. Asia-Pacific Journal of Cooperative Education, 7(2), 1-9.

Stephens, K. K., \& Mottet, T. P. (2008). Interactivity in a web conference training context: Effects on trainers and trainees. Communication Education, 57(1), 88-104.

Stone, C. (2005). Promoting an integrated campus-wide approach to first year student retention. Journal of the Australia and the New Zealand Student Services, October, 26, 33-40.

Tinto, V. (1993). Leaving college: Rethinking the causes and cures of student attrition (2nd ed.). Chicago: University of Chicago.

Vygotsky, L. (1978). Interaction between learning and development. In Gauvain \& Cole (Eds), Readings on the development of children (pp. 34-40). New York: Scientific American Books. 
Woods, E.G. (1995). Reducing the dropout rate. School Improvement Research Series (SIRS). Retrieved October 13, 2000 from http://www.nwrel.org/scpd/sirs/9/c017.html

Zeichner, K., \& Liston, D. (1987). Teaching student teachers to reflect. Harvard Education Review, 57(1), 23-48.

\section{Biographies}

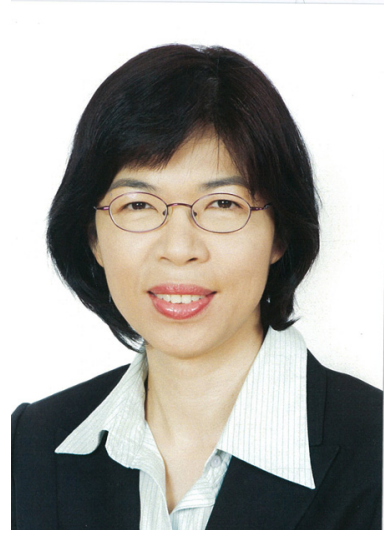

Dr. Michelle W. L. Fong is a senior lecturer in the School of Economics and Finance, Victoria University. She has taught in Australia, China, Malaysia, and Singapore. Prior to her academic and research career, she worked with a range of organizational systems in corporations based in different countries. Her research interest includes information technology applications, e-business, and online education.

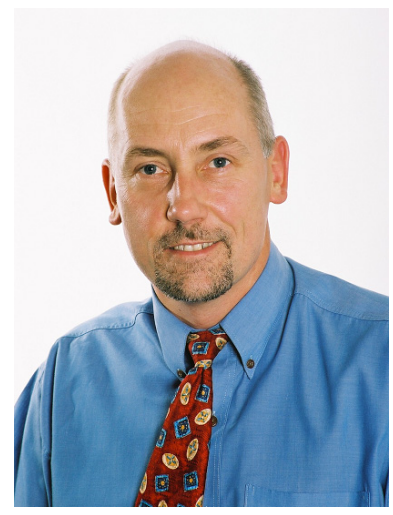

Rob Sims is a senior lecturer in Accounting and Professional Development for the Faculty of Business and Law at Victoria University. His main teaching areas are management accounting, professional development and business research methods. He is experienced in the application of quantitative and qualitative data collection and analysis. He is a CPA and a Registered Tax Agent and has extensive experience in accounting and consulting to small businesses, large corporations and government organisations. Consultancies have included financial analysis and modeling, development of performance indicators, advice on accounting policy, financial management training, training needs analysis and software development. He has also had considerable experience in the design and conduct of a wide range of research and consulting projects, many with associated publications. 